\title{
CHARACTERISTICS AS WELL AS PAST AND PRESENT POSSIBILITIES OF USING MICROORGANISMS LISTED ON THE CDC LIST A OF BIOLOGICAL AGENTS IN BIOTERRORIST ATTACKS
}

\section{CHARAKTERYSTYKA ORAZ HISTORYCZNE I WSPÓŁCZESNE MOŻLIWOŚCI UŻYCIA DROBNOUSTROJÓW ZNAJDUJĄCYCH SIĘ NA LIŚCIE A CZYNNIKÓW BIOLOGICZNYCH CDC W ATAKU BIOTERRORYSTYCZNYM}

\author{
Marcin Weiner $^{1(\mathrm{~A}, \mathrm{~B}, \mathrm{C}, \mathrm{D}, \mathrm{E}, \mathrm{F}, \mathrm{G})}$, Karolina Tarasiuk $^{1(\mathrm{~A}, \mathrm{~B}, \mathrm{C}, \mathrm{D}, \mathrm{E}, \mathrm{F})}$ \\ ${ }^{1}$ Pope John Paul II State School of Higher Education in Biała Podlaska, Poland
}

Authors' contribution Wkład autorów: A. Study design/planning zaplanowanie badań B. Data collection/entry zebranie danych C. Data analysis/statistics dane - analiza i statystyki D. Data interpretation interpretacja danych E. Preparation of manuscript przygotowanie artykułu F. Literature analysis/search wyszukiwanie i analiza literatury G. Funds collection zebranie funduszy
Tables: 0

Figures: 0

References: 24

Submitted: 2017 March 24

Accepted: 2017 May 29

\section{Summary}

The study aims at characterising four bacterial infectious agents listed on the CDC A list, i.e. Anthrax (Bacillus anthracis), plague (Yersinia pestis), botulism (Clostridium botulinum) and tularemia (Francisella tularensis) as potential tools used in a bioterrorist attack causing diseases. The paper also includes information on their occurrence in Poland and the EU. Despite the real threat of terrorism in the $21^{\text {st }}$ century and large-scale activities aimed at limiting the occurrence of this phenomenon, it should be borne in mind that pathogens listed on the CDC list A, although spotted primarily in animals, can be a real threat to people's health and life. Among the discussed microorganisms, only Francisella tularensis and Clostridium botulinum cause sporadic diseases in Poland; however, it should be remembered that both Bacillus anthracis, occurring in Europe, and Yersinia pestis, occurring in Asia and Africa, can pose real threats to human health and life not only in natural infections, but when used as a biological weapon.

Keywords: Francisella tularensis, bioterrorism, Bacillus anthracis, Yersinia pestis, Clostridium botulinum

\section{Streszczenie}

Celem pracy jest charakterystyka czterech bakteryjnych czynników zakaźnych oraz wywoływanych przez nie jednostek chorobowych znajdujących się na liście A CDC jako potencjalnych narzędzi stosowanych w ataku bioterrorystycznym: wąglika (Bacillus anthracis), dżumy (Yersinia pestis), botulizmu (Clostridium botulinum) oraz tularemii (Francisella tularensis). W pracy zamieszczono również informacje na temat ich występowania w Polsce i UE. Pomimo realnego zagrożenia terroryzmem w XXI wieku i zakrojonych na szeroka skalę działań mających na celu ograniczenie występowania tego zjawiska, należy mieć na uwadze, że patogeny wymienione na liście A CDC, mimo, że występują przede wszystkim u zwierząt, mogą stanowić realne zagrożenie zdrowia i życia ludzi. Wśród omawianych drobnoustrojów, jedynie Francisella tularensis i Clostridium botulinum wywołują sporadyczne zachorowania w Polsce, jednak należy mieć na uwadze że zarówno Bacillus anthracis występujący w Europie oraz Yersinia pestis wystepująca w Azji i Afryce mogą stanowić realne zagrożenia dla zdrowia i życia człowieka nie tylko $\mathrm{w}$ przypadku naturalnych zakażeń, ale przede wszystkim w przypadku użycia ich jako broni biologicznej.

Słowa kluczowe: Francisella tularensis, bioterroryzm, Bacillus anthracis, Yersinia pestis, Clostridium botulinum

Weiner M, Tarasiuk K. Characteristics as well as past and present possibilities of using microorganisms listed on the CDC list A of biological agents in bioterrorist attacks. Health Prob Civil. 2019; 13(1): 76-82. https://doi.org/10.5114/hpc.2018.78910

Address for correspondence / Adres korespondencyjny: Marcin Weiner, Pope John Paul II State School of Higher Education in Biała Podlaska, Sidorska 95/97, 21-500 Biała Podlaska, Poland, e-mail: mpweiner@o2.pl, phone: +48 833449900

ORCID: Marcin Weiner https://orcid.org/0000-0001-9288-0823 Karolina Tarasiuk https://orcid.org/0000-0002-5926-5121

Copyright: (C) Pope John Paul II State School of Higher Education in Biała Podlaska, Marcin Weiner, Karolina Tarasiuk. This is an Open Access journal, all articles are distributed under the terms of the Creative Commons Attribution-NonCommercial-ShareAlike 4.0 International (CC BY-NC-SA 4.0) License (http://creativecommons.org/licenses/by-nc-sa/4.0/), allowing third parties to copy and redistribute the material in any medium or format and to remix, transform, and build upon the material, provided the original work is properly cited and states its license. 


\section{Introduction}

Bioterrorism is one of many types of broadly understood terrorist activities, involving the use of bacteria, viruses or toxins to destabilise the economic system of the state or trigger epidemics that can lead to the death of a large number of people in a short time [1].

In 2000, the Centre for Disease Control and Prevention (CDC) based in Atlanta published a list of biological agents that could be used in a potential biological attack and which can be classified into 4 groups (A, B, C and D). The group of the highest risk are bacterial and viral infectious agents included in list A [2].

The aim of the following study is to characterise the four bacterial infectious agents found on $\mathrm{A}$ list $\mathrm{A}$ and present information on their occurrence in Poland and the EU.

\section{Bacillus anthracis - anthrax}

The first records of human anthrax disease come from antiquity in the works by Hippocrates and Virgil. In 1877, Koch developed his postulates describing it as the perpetrator of an infectious disease and, a dozen years later, Louis Pasteur made the first vaccine against anthrax in animals. During the Second World War, Japan carried out intensified research on bacteriological weapons in the area of Manchuria. To this end, two units were established: the first - unit 731, which was strictly interested in the development of bacteriological weapons, and the other one - unit 710, which was to apply the theoretical knowledge gained by the first team in practice [3].

During the Second World War, Great Britain also conducted research related to the use of bacteria as a biological weapon. In 1941, an experiment was carried out with bombs containing anthrax on an unpopulated Griunard island near Scotland. As a result of this incident, the survival forms of anthrax were recorded for almost 50 years after the discontinuation of the research [4].

In turn, the United States began research into bacteriological weapons in the years 1941-1943. For this purpose, Camp Detrick research centres (now Fort Detrick) and Camp Frederick were built [5]. Initially, the research programme included only anthrax spores, bacteria of the Brucella genus; however, in a short time it was extended to other pathogens (plague, cholera, Q fever) [5].

During the Cold War, scientists from the USSR skilfully used the knowledge of German engineers who were taken prisoners of war. They also broadened their knowledge thanks to the materials obtained during the Manchuria occupation. In the 1970s, in Sverdlovsk, under the camouflage of biotechnology research, the Soviet Union carried out a research programme into biological weapons called "Biopreparat". Due to the negligence of one of the employees of the complex 19, a catastrophe happened. The improper oversight of the personnel resulted in airborne dust entering the atmosphere (it is estimated that about $1-2 \mathrm{~g}$ of anthrax spores was released), which spread to the areas close to the research centre with the wind [6]. The data on people infected and deaths in Sverdlovsk vary and range from 79 to 96 persons infected with anthrax, and 68 to 105 dead. [8].

After the attack on the World Trade Centre and the Pentagon, on September 11, 2001, the first letters with anthrax spores were sent to television stations, the headquarters of the New Jersey Post, and to American Media in Florida. As a result of these incidents, 5 people died. Public institutions, and, in particular the buildings of the Supreme Court, Congress as well as post offices, were contaminated [7].

It was Saddam Hussein, the Iraqi leader, who was blamed for the attack using anthrax. The rumour about combining anthrax with bentonite, which was supposed to make it more volatile, and a statement about the modification of $B$. anthracis spores with silicon into a bacteriological weapon, turned out to be untrue. However, in 2002, it was discovered that the terrorist organization Al-Khaida was preparing for a bioterrorist attack with the use of anthrax bacilli in Afghanistan [5, 7].

Anthrax is caused by bacillus anthracis. The etiologic agent of anthrax is Gram-positive sporangiae, whose vegetative form is about $3-10 \mu \mathrm{m}$ long. The characteristic features of anthrax macrophages include the lack of red blood cell production, inactivity, growth in the atmosphere with an increased content of CO2, as well as the production of spores in the presence of oxygen. In the surviving form, anthrax bacilli exhibit very high resistance to environmental factors, low and high temperature, $\mathrm{pH}$ changes, drying and most disinfectants. There is a polypeptide shell containing D-glutamic acid in B. anthracis virulent strains that determines bacterial resistance to phagocytosis and lysis. $B$. anthracis produces three exotoxins: a protective antigen (PA), a lethal factor (LF), an edema factor (EF), which act synergistically. LF inhibits phagocytosis and stimulates IL-1 TNF- $\alpha$ synthesis leading to toxemia. Increasing the concentration of cAMP, EF causes tissue edema [9].

Human infections are rare, usually by direct contact or by products of animal origin (meat intake, contact with contaminated skin and hair). The basic reservoir of anthrax bacilli is the soil in which the bacterial spores can survive for years. 
The occurrence of anthrax in humans in natural conditions is associated with the presence of bacteria among domestic animals. Above all, one gets ill after a direct contact with sick animals, blood, secretions and excretions. For this reason, people involved in agriculture, i.e. farmers, shepherds, butchers, technicians and veterinary surgeons, are most vulnerable to becoming ill. Also, those working in the broadly understood processing of animal-derived materials are endangered. There were recorded some cases of people becoming ill after contact with clothes contaminated with anthrax (wearing fur) and in people using heroin intravenously. The infection is much less frequent in the droplet (5\%) and food (about 1\%) transmission [10].

The incubation period is short and ranges from 1 to 7 days. The most common and, at the same time, the mildest form of anthrax is the skin form. The lung form is less frequently observed, which results from the use of anthrax as a biological weapon or, as described above, an accident in Sverdlovsk. When intestinal bacteria are ingested, intestinal and oropharyngeal forms may develop [14].

The cutaneous form of anthrax develops due to the penetration of bacterial spores in the abrasion area, its cutting or insect bites. Initially, an itchy papule appears, which grows days into a follicle within 2-3, and then transforms into a pustule with a scab surrounded by painless shaft with blisters (black pustules) [9].

The pulmonary form of anthrax occurs following the inhalation of a significant amount of spores (from 8-10,000). The first symptoms appear after 1-4 days. If the infection dose is a small, the incubation period is up to 60 days. In this form, the disease has a two-phase course. The first phase is characterised by low fever, dry cough and malaise. After a period of relative improvement, the patient's condition deteriorates rapidly and high fever, shortness of breath, cyanosis and retrosternal pain appear. In the final stage, anthrax is disseminated to the CNS leading to toxemia with sepsis. Irrespective of the used antibiotics in this stage, mortality is very high and amounts to over $90 \%$ [11].

Oral-pharyngeal and intestinal forms occur sporadically and depend on the place of entry of the microorganism into specific sections of the gastrointestinal tract. In the oropharyngeal form, ulcers resembling skin forms appear within the oral mucosa, hard palate and throat. Conditions characteristic of this form include: sore throat, difficulty in swallowing, fever and swelling of neck tissues. In the intestinal form, the place of penetration of the microorganism concerns the cecum and is characterised by the occurrence of nausea, vomiting, bloody diarrhea and later occlusion of the gastrointestinal tract [10].

The drugs of choice are penicillin, doxycycline and fluoroquinolones. Therapy with the addition of rifampicin, clindamycin or chloramphenicol is also warranted. Treatment usually lasts for 14 days, but in severe cases it can be extended up to 60 days [10].

Routine laboratory testing for the identification of anthrax bacillus includes microscopic examination, multiplication and isolation of the germ together with its biochemical identification and drug resistance, a biological test on laboratory animals and a serological test for the detection of antigen in the capsular anthrax bacilli (Ascoli thermocapsule reaction) or factors exoticoxin traits (ELISA) [9]. Direct microscopic examination consists in the search for enveloped, Foth-fixed or Olta-type bacilli, or by the Fadyean method, or in the preparations of organ imprints using the Gram method. The presence of Gram-positive bacilli, arranged in structures resembling a bamboo stick, suggests an anthrax infection. Isolation and culture includes cultures from blood or tissue sections on plain agar, agar with 5\% sheep blood and selective media, PLED B and PLED A. On a solid medium, anthrax bacilli form colonies with a very characteristic fibrous structure and jagged jelly-like edges. There are also new diagnostic techniques that are successfully used which include: gas chromatography for a direct detection of $B$. anthracis metabolic products, PCR techniques using primers complementary to plasmid DNA to detect the presence of spores or vegetative forms, and improved immunoenzymatic techniques for the detection of PA antigen and exotoxins of anthrax bacilli with the use of monoclonal bodies [9].

According to the ECDC, in 2014, there were 16 cases of anthrax in the European Union (9 in Hungary, 4 in Spain, 2 in Romania and 1 in Greece). In 2011, there were 5 cases ( 2 in Romania and Greece, 1 in Bulgaria), in 2012 - 14 cases (6 in the United Kingdom, 4 in Germany, 1 in France, 2 in Denmark, 1 in Bulgaria). In 2013, the number of cases decreased to 6, with one case reported in Bulgaria, Croatia, Portugal, Romania and two cases in Great Britain. No cases of anthrax were reported in Poland in humans in the years 2011-2016, [12].

\section{Clostridium botulinum - botulism}

Another disease - botulism - poisoning after consumption of sausage (sausage - botulus in Latin), was first described by Leon VI, a Byzantine emperor and philosopher, living at the turn of the 9th and 10th centuries. In the United States, the first case of poisoning with botulinum toxin was recorded in 1735 and the source of infection was sausage, but other cases involved other food products of animal origin. The research on the possibility of using botulinum toxin as a biological weapon was carried out during the Second World War (Japan, USSR, the United States) [13]. 
Generally, to date, no botulinum toxin has been reported during military operations, despite advanced scientific programmes on its use as a bacteriological weapon by the world armies (Japan - the 1930s, Great Britain and Canada - the Second World War, the United States and the USSR - the cold war). In 1990, members of the Japanese sect the Supreme Truth attempted to spread $C$. botulinum in the centre of Tokyo. The trials ended in failure due to difficulties in obtaining a toxin in the form of a spray [14].

Botulism can develop after eating food containing a bacterial toxin, bacterial cells themselves, but also by absorbing the toxin present in wounds infected with $C$. botulinum. There is also the possibility of the aerogenic route of toxin infections. Traditionally, botulism is divided into food poisoning, wound infection, botulism in infants and botulism of unknown etiology (intestinal).

C. botulinum is a Gram-positive, anaerobic spore-producing rod. The characteristic feature of the microorganism is the production of toxins marked with letters A to G. Toxins A, B, E, F are responsible for human disease, whereas toxins $C$ and $D$ - in animals, while the role of toxin G is not fully understood. Poisoning with toxins $A$ and $B$ is associated with food intake of animal or vegetable origin, whereas toxic E toxicity results from the consumption of fish products. Individual toxins differ in amino acid composition, susceptibility to proteolytic enzymes and lack of cross-reactivity of neutralising antibodies, which means in practice that the A-antitoxin does not neutralise toxins belonging to other types. Botulinum toxin is the strongest of the known natural toxins. It is believed that $1 \mathrm{~g}$ of botulinum toxin can kill over a million people. The toxin is a protein complex consisting of a light chain with a molecular weight of approximately $50 \mathrm{kDa}$, and a heavy $10 \mathrm{kDa}$, connected by a disulfide bridge. It has found application in medicine and cosmetology, where it is used to smooth out facial and neck wrinkles. The mechanism of action of the toxin is to inhibit the release of acetylcholine, in synapses of the peripheral system between motor neurons and muscle fibers, which leads to their paralysis. The return to the proper muscle function occurs after the formation of a damaged synapse and lasts from 3 to 6 months [13].

All forms of botulism are related to the absorption of the toxin into the circulatory system from the surface of mucous membranes of the digestive and respiratory systems as well as from wounds. It should be noted that the toxin is not able to penetrate skin that is intact. In the case of food poisoning, the onset of the disease is sudden and ranges from 18 to 36 hours. Neurological symptoms may be preceded by gastrointestinal complaints (vomiting, abdominal pain, diarrhoea) and malaise. The severity and extent of the lesions depends mainly on the dose of neurotoxin. The disease is characterised by acute bilateral symmetrical nerve damage ranging from cranial nerves and descending paresis or muscle paralysis. The patient is conscious, fully oriented and does not get feverish. Other common symptoms include: dry mouth, double vision due to paralysis of muscles that move the eyeball hypersensitivity to light. Then, there are symptoms of bulbar palsy, swallowing difficulties and speech disorders. There is a progressive weakening of the respiratory muscles, as well as muscles in the limbs and torso. In the case of contamination of wounds with the botulinum toxin, the same neurological symptoms are found; however, there are no gastrointestinal complaints. In the case of infant botulism, the symptoms depend on the degree of neuromuscular paralysis and include weak crying, weakness of sucking ability, dysphagia, general weakness (the so-called faint child), respiratory failure and apnea [14].

The source of infection in food poisoning is improperly conserved food contaminated with a botulinum toxin. If the wound is infected with a botulinum toxin, the source of the infection is soil contaminated with bacteria. In addition, botulism occurs in people who have undergone various types of injuries such as: deep stab wounds, incorrectly treated open fractures and in those who inject drugs. In the case of infant botulism, the disease is caused by ingestion of $C$. botulinum spores, then a toxin is produced in the child's body. The most common source of bacteria in this case is honey or corn syrup administered to infants [13].

Botulism therapy includes combined specific and symptomatic treatment. Specific treatment involves the administration of anti-blotting serum containing antibodies that neutralise the toxin. The most frequently used antitoxin is foreign species (horse), and sometimes - human immunoglobulins. It is believed that the antitoxin is effective up to 72 hours after the onset of the first symptoms. Due to the necessity of fast antitoxin administration with a simultaneous long period of identification of the type of toxin, multipurpose preparations, i.e. mixtures of A + B + E antitoxins [14,] are used.

The laboratory diagnosis of botulism includes direct techniques; that is a detection of botulinum toxin in patients' blood serum or in other biological material, as well as a indirect detection of botulinum toxin or a toxinogenic strain in food or feed whose consumption was preceded by the onset of symptoms of poisoning. Isolation and cultivation of $C$. botulinum is performed on liquid and solid Wrzoska-Sheadler media or VL substrates. Samples with sown substrates are divided into two groups: the first are heated at 75 degrees for 35 minutes, the other remain without heating [13].

As the ECDC indicates, there were 123 persons diagnosed with the disease in 2014, with the statistical data coming from 29 European countries. The highest incidence rates were recorded in Romania (31), Poland (17) 
and Hungary (12). In former years, the number of cases was as follows: in 2011 there was an increase to 115 cases (21- in Poland, 24 in Italy and 18 in Romania), in 2012 there was a drop in Europe compared to previous years to 72 cases ( 9 cases in Poland, whereas in Italy 20 and in Romania 15). In 2013, there was another increase in incidence -82 cases (9 in Poland, 25 in Romania and 15 in France) [12].

\section{Yersinia pestis - plague}

Black plague (black death) was known in antiquity. It is mentioned already in the records by Thucydides or even the book of Samuel of the Old Testament. The plague epidemic also affected ancient Rome under Marcus Aurelius, when it claimed the lives of nearly 70 million people, while Justyniana's plague, lasting less than half a century, caused the deaths of about 10 million Roman citizens. The next plague epidemic returned to Europe only in the Middle Ages. The climate conditions at the end of the thirteenth century in Europe, with the simultaneous increase in population, caused shortages of food, which in turn affected the resilience of people and livestock. At the beginning of the $14^{\text {th }}$ century, famine affected the north-western part of Europe, reducing the size of the continent's population by about $10 \%$ [15].

The etiological factor of the plague is the bacterium Yersinia pestis, which was used for the first time during the biological siege of Kaffa (today's Crimea) by the Tartars (1346), who threw the body of the plague-infected patients across the city walls. Watching the rapid spread of the plague in the city, Kaffa defenders began to flee from the battlefield to Venice, Genoa, Constantinople and other ports in the Mediterranean. Probably this event was the cause of the most famous pandemic plague in Europe [15].

The black death pathogen was also used in 1422 at the Battle of Carolstein and in 1710 during the RussoSwedish War, when the Russians captured Reval - today's Talin, by transferring infected corpses through the city walls [16]. The plague epidemic also affected Toruń in 1708, where during 5-month period over 4,000 people died. From the mid-sixteenth to the mid-eighteenth century, plague haunted Torun up to sixteen times.

Since 1932, Japanese scientists multiplied the production of Y. pestis bacteria and bred fleas and rats infected with the pathogen, and its effectiveness was verified on prisoners of war and the Chinese population [17]. During the Cold War, research into the use of the microorganism as a bacteriological weapon was conducted by the Soviet Union and the United States. American scientists, however, interrupted these studies in 1969, whereas Soviet biologists continued them until the nineties of the twentieth century [6, 7].

Plague is an acute infectious disease spreading enzootically among rodents and transmitted to humans by fleas. The basic forms of this disease are bubonic plague (pestis bubonica), pneumonic plague and occasional sepsis plague. The etiological factor is $Y$. pestis, which belongs to the Enterobacteriaceae family. It assumes the shape of a small-sized kernel, dyes bipolarly, and is relatively anaerobic and catalase-sensitive [18].

The incubation period of the disease is about 6 days and covers the time elapsing from the skin puncture by flea in the form of a cigarette or respiratory infection in the pulmonary form. The fumed form is characterised by a variety of clinical features. Symptoms include: fever, drowsiness, drowsiness or arousal, enlarged lymph nodes, inguinal and axillary, painfulness, softness and spontaneous puncture. A successful prognosis for the follicular form concerns only half of the patients. The pulmonary form proceeds rapidly, often even staggering. There appear symptoms of respiratory failure (dyspnoea, cyanosis), cough with profuse sputum and disturbances of consciousness. In the post-septic form, there may occur intravascular coagulation (DIC) with haemorrhagic diathesis and necrosis of the distal limbs [19].

The primary treatment is the antibiotic treatment with doxycycline, streptomycin, gentamicin, chloramphenicol, cephalosporins and carbapenems [12].

The detection and diagnosis of $Y$. pestis requires a routine examination including microscopic examination of a direct material, which is most often blood, exudation or purulence, isolation and cultivation of the germ from pleural effusion and sputum, as well as a biological test consisting in infecting a guinea pig with the material collected from the patient.

According to the ECDC, the highest incidence occurred in 201, in Madagascar, when 482 cases were reported infected and 81 people died. In the African countries of the Democratic Republic of Congo and the aforementioned Madagascar, there were $97 \%$ of all cases occurring all over the world. Plague has not been observed in Europe for years; however, it is found sporadically on the eastern slopes of the Caucasus, in China, Mongolia, Vietnam, Cambodia, Indonesia, Iran up to the borders of Saudi Arabia and Yemen. In Africa, active outbreaks of plague occur in South Africa, Namibia, Lesotho, Kenya, Tanzania and Mozambique. In North America, plague is endemic in the 15 western states $[12,20]$. The last cases in Poland were recorded in the south-eastern borderlands at the end of the $18^{\text {th }}$ century. 


\section{Francisella tularensis - tularemia}

In antiquity (the end of the fourteenth century BC), tularemia was known and used by Hittites, who would use infected animals to spread the disease to the enemy. Hence, tularemia is known as the "Hittite epidemic" or the "Hittite disease" [6, 7, 21].

Tularemia was first described in Japan in the late nineteenth century, but the name Francisella comes from Edward Francis, an American researcher who discovered these bacteria in 1911 in squirrels in Tulare County, California. In humans, this disease was first described in 1924 in a patient with severe pneumonia, with spleen and lymph node damage [22].

The first works on the use of $F$. tularensis as biological weapons were carried out in the 1930s simultaneously in the US, USSR and Japan [23]. It is believed that the mass incidence in German soldiers in the years 19421943, during the siege of Stalingrad, was the result of the use of these bacteria by Soviet soldiers. Then, these rods were successfully tested in Manitoba in 1932-1945 and research on potential use as a biological weapon continued after the end of the Second World War in both the US and the USSR. In spite of the official declaration by the USSR in 1973 concerning the destruction of the arsenal of biological weapons, work on these bacteria was also carried out in the early 90 s of the twentieth century $[6,7,17]$.

In Poland, for the first time tularemia was diagnosed in humans in 1949 in Łódź, and the source of the disease was hare skin. Subsequent cases were noted in the 1950s as a result of contact with rabbits and laboratory animals [7].

Tularemia is an acute zoonotic infectious disease found in natural conditions in rodents and rabbits. Cattle, pigs, dogs, cats, domestic and wild birds, non-domestic animals, and primate also suffer from tularemia. It is caused by the small, relatively aerobic, intracellular Gram-negative rod Francisella tularensis, with the dimension 0.2-0.3 $0.7 \mu \mathrm{m}$, characterised by high variability of shapes. F. tularensis rods are sensitive to high temperature and most commonly used disinfectants. However, the bacteria are killed within 30 minutes when exposed to the influence of sunlight, at $58{ }^{\circ} \mathrm{C}-10$ minutes. They survive for a relatively long time in the natural environment; in soil and water reservoirs for over 3 months and in the frozen state - even for a few years [12].

The disease can occur through vectors such as flies, ticks and mosquitoes. Ticks can be a natural reservoir of this microorganism for a long time and the cause of frequent epidemics and epizootics in a given area. Human infection occurs due to contact with sick animals or inhaling dust contaminated with animal droppings, which takes place mainly in farms dealing producing animals and, to a lesser extent, due to contaminated food and water. It is also possible to transfer the micro-organism through the conjunctiva or damaged skin.

Tularemia occurs in several clinical forms. The most common (45-85\%) form is ulcer-nodal, resulting from a contact with contaminated tissues of animals or bites by infected arthropods [19]. At the site of infection, clots appear, which after 48 hours are $1-2 \mathrm{~cm}$ in size. Next, they turn into pustules and then ulcers. The bacteria then pass to the lymph nodes and from there to the internal organs or CNS. The consequence of consuming contaminated food, feed or water may be two further forms of tularemia: gastrointestinal and anginal. The first one most often takes the form of mild diarrhoea, or a more severe one, manifesting itself with intestinal ulceration, the other one - the angina form is an exudative inflammation of the mouth and throat, which is accompanied by swelling of the lymph nodes of the neck, whose common complication may be pneumonia. The consequence of the penetration of the microorganism via the aerogenic pathway, but also as a complication of other forms of tularemia, is the pulmonary form, occurring in less than $5 \%$ of cases. The disease may take the form of hyperacute or, with slowly emerging clinical symptoms, have a non-specific character: fever, muscle pain, chest pain, dry cough and pneumonia. It can enlarge nodal lymph nodes and cause effusion in the pleural cavity. There appear also granulomatous changes in lung tissue as well as abscesses. Rare forms of tularemia are the ocular node, which are the result of the mechanical introduction of conjunctival bacilli (rubbing the eyes with the fingers) and the major form, characterised by sudden fever without skin lesions, muscle pain, headache, chills. The complication of this form is the breakdown of striated muscles, inflammation of the liver, kidneys, meninges and joints. In the major form, mortality is very high and reaches $50 \%$ [23].

Bacteriological research towards F. tularensis involves culturing the tested biological material on appropriate solid microbiological media, i.e. CHA agar medium (Cystine Heart Agar) and CHA + SS selective agar medium (with the addition of inhibiting substances) growth of foreign bacterial flora. Identification of $F$. tularensis involves the following tests: oxidase test $(-)$, catalase test $(+)$, slide agglutination test with anti-F serum. tularensis $(+)$, Gram stain (Gram negative cocoons) [23, 24].

According to the ECDC, in 2015 in the EU countries (with no data from Denmark, Malta and Portugal), there were 1,079 human cases detected in laboratories, which represents an increase of nearly $125 \%$ in relation to 2014. At the same time, 9 infections were recorded in Poland. There were 6 cases in Poland in 2011 (544 in the EU), 6 cases in 2012 (in the EU 942), and in 2013 there was noted an increase to 8 cases (a drop to 279 in the EU). In 2014, the highest number of cases was recorded in Poland in 5 years (11 cases). In the same year, 480 
cases were reported in the EU. In 2015, the disease was most commonly found in Sweden (859 people), Finland (104), the Czech Republic (56) and Hungary (35). There was not a single case of its occurrence in Estonia, Greece, Latvia, Luxembourg, Portugal and Slovenia [12].

Despite the real threat of terrorism in the $21^{\text {st }}$ century and large-scale activities aimed at reducing the occurrence of this phenomenon, it should be borne in mind that pathogens listed on the CDC list A may pose a real threat to human health and their lives.

\section{References:}

1. Puzanowska B, Czauż-Andrzejuk A. [Bioterrorism]. Przegląd epidemiologiczny. 2001; 55: 379-386 (in Polish).

2. Centers for Disease Control and Prevention. Biological and chemical terrorism: strategic plan for preparedness and response - recommendations of the CDC strategic planning workgroup. Morb Mortal Wkly Rep MMWR. 2000; 49: 1-14.

3. Janeczek M, Chrószcz A, Ożóg T. [The use of biological and chemical weapons in Ancient World and the role of epidemic diseases in the history]. Życie Weterynaryjne. 2010; 85: 230-233 (in Polish).

4. Zajkowska J, Hermanowska-Szpakowicz T. [Anthrax as biowarfare weapon]. Medycyna Pracy. 2002; 2: 167172 (in Polish).

5. Zieliński KW. [Pathology of injures and illnesses caused by modern weapons in warfare and terrorism]. Warszawa: MON; 2010 (in Polish).

6. Bińczycka-Anholcer M, Imiołek A. [Bioterrorism as a form of modern terrorism]. Hygeia Public Health. 2011; 3: 327 (in Polish).

7. Chomiczewski K. [Animal pathogens as a biological weapon]. Przegląd epidemiologiczny. 2003; 57: 355-61 (in Polish).

8. Meselson M, Guillemin J, Hugh-Jones M, Langmuir A, Popova I, Shelokov A, et al. Sverdlovsk anthrax outbreak of 1979. Science. 1994; 266: 1202-08. https://doi.org/10.1126/science.7973702

9. Rao SS, Mohan KV, Atreya CD. Detection technologies for Bacillus anthracis: prospects and challenges. J Microbiol Methods. 2010; 82(1): 1-10. https://doi.org/10.1016/j.mimet.2010.04.005

10. Bouzianas DG. Potential biological targets of Bacillus anthracis in anti-infective approaches against the threat of bioterrorism. Expert Rev Anti Infect Ther. 2007; 4: 665-84. https://doi.org/10.1586/14787210.5.4.665

11. Derzelle S, Thierry S. Genetic diversity of Bacillus anthracis in Europe: genotyping methods in forensic and epidemiologic investigations. Biosecur Bioterror. 2013; 1: 166-76. https://doi.org/10.1089/bsp.2013.0003

12. European Food Safety Authority, European Centre for Disease Prevention and Control. The European Union summary report on trends and sources of zoonoses, zoonotic agents and food-borne outbreaks in 2015. EFSA Journal. 2016; 14(12): e04634. https://doi.org/10.2903/j.efsa.2016.4634

13. Kukier E, Kwiatek K, Grenda T, Goldsztejn M, Dębski J. [Botulism - pathogenesis and diagnostics of the disease]. Życie Weterynaryjne, 2015; 90: 163-166 (in Polish).

14. Dembek ZF, Smith LA, Rusnak JM. Botulism: cause, effects, diagnosis, clinical and laboratory identification, and treatment modalities. Disaster Med Public Health Prep. 2007; 1: 122-34. https://doi.org/10.1097/DMP.0b013e318158c5fd

15. Janofsky M. Looking for motives in plague case. New York Times. May 24, 1995: A12.

16. Bennett JM, Hollister CW. Medieval Europe: A Short History. New York: McGraw-Hill; 2006. p. 326.

17. Barras V, Greub G. History of biological warfare and bioterrorism. Clin Microbiol Infect. 2014; 6: 497-502. https://doi.org/10.1111/1469-0691.12706

18. Christian MD. Biowarfare and bioterrorism. Crit Care Clin. 2013; 3: 717-56. https://doi.org/10.1016/j.ccc.2013.03.015

19. Lõhmus M, Janse I, van de Goot F, van Rotterdam BJ. Rodents as potential couriers for bioterrorism agents. Biosecur Bioterror. 2013; 1: 247-57. https://doi.org/10.1089/bsp.2012.0085

20. Prentice MB, Rahalison L. Plague. Lancet. 2007; 369(9568): 1196-207. https://doi.org/10.1016/S0140-6736(07)60566-2

21. Robinson-Dunn B. The microbiology laboratory's role in response to bioterrorism. Arch Pathol Lab Med. 2002; 3: 291-4.

22. Kłapeć T, Cholewa A. [Tularemia - a still dangerous zoonosis]. Medycyna Ogólna. Nauki o Zdrowiu. 2011; 3: 155-160 (in Polish).

23. Maurin M, Gyuranecz M. Tularaemia: clinical aspects in Europe. Lancet Infect Dis. 2016; 1: 113-24. https://doi.org/10.1016/S1473-3099(15)00355-2

24. Wagar E. Bioterrorism and the role of the clinical microbiology laboratory. Clin Microbiol Rev. 2016; 29; 17589. https://doi.org/10.1128/CMR.00033-15 